\title{
Rakitis Nutrisi Akibat Diet Vegan pada Ibu Hamil dan Menyusui
}

\author{
Basuki Supartono ${ }^{1}$, Ayola Dewi Utami ${ }^{2}$, Prita Kusumaningsih ${ }^{3}$ \\ Departemen Bedah Ortopedi, Fakultas Kedokteran UPN Veteran Jakarta ${ }^{1,2}$ \\ JI. RS Fatmawati, Pondok Labu, Jakarta Selatan 12450 \\ Bagian Kebidanan dan Kandungan, Rumah Sakit Umum Al Fauzan Jakarta ${ }^{3}$ \\ Jl. Pedati, Kramat Jati, Jakarta Timur 13540 \\ E-mail: basuki@upnvj.ac.id,
}

\begin{abstract}
Abstrak
Diet vegan belakangan ini menjadi semakin populer di Eropa dan negara lainnya termasuk Indonesia. Pola seperti itu bila dijalankan oleh ibu hamil dan menyusui berpotensi menimbulkan kekurangan nutrisi dan menyebabkan gangguan kesehatan tulang anak. Review ini bertujuan untuk mengetahui risiko diet vegan pada ibu hamil dan ibu menyusui. Hasil review memperlihatkan bahwa diet vegan pada ibu hamil dan menyusui dapat menganggu kesehatan tulang anak. Kesimpulan review adalah rakitis nutrisi dapat terjadi akibat diet vegan pada ibu hamil dan menyusui. Sehubungan dengan hal diatas perlu dilakukan edukasi pada ibu hamil dan menyusui yang melakukan diet vegan untuk mencegah timbulnya masalah tersebut. Review ini membahas efek diet vegan terhadap kesehatan tulang anak, pencegahan dan tatalaksananya.
\end{abstract}

Kata Kunci: Diet Vegan, Rakitis, Rakitis Nutrisi, Vitamin D

\section{Nutritional Rickets due to the Vegan Diet in Pregnant and Breastfeeding Women}

\begin{abstract}
The vegan diet has recently become increasingly popular in Europe and other countries, including Indonesia. Such a diet in pregnant and lactating women can cause nutritional deficiencies and lead to rickets. This review article aims to find out the risks of the vegan diet in pregnant and nursing mothers. The review results showed that a vegan diet in pregnant and nursing mothers could interfere with the child's bone health. This review concludes that nutritional rickets can occur due to a vegan diet in pregnant and nursing mothers. It is mandatory to educate pregnant and nursing mothers on a vegan diet to prevent this problem.

This review examines the effects of a vegan diet on children's bone health, prevention, and management.
\end{abstract}

Keywords: Vegan Diet, Rickets, Nutritional Rickets, Vitamin D 
Rakitis Nutrisi Akibat Diet Vegan pada Ibu Hamil dan Menyusui

Basuki Supartono, Ayola Dewi Utami, Prita Kusumaningsih

\section{PENDAHULUAN}

Pola makan vegan dan vegetarian belakangan ini semakin populer di Eropa dan di berbagai negara termasuk Indonesia. Prevalensinya di kalangan remaja dan orang dewasa di negara Eropa berkisar antara 0,2 hingga $3 \%$. Sebagian besar mereka telah melakukan pola makan tersebut dalam waktu lama antara 5 sampai dengan 11 tahun. Karakteristik mereka di antaranya adalah orang muda dengan status sosial ekonomi tinggi dan gaya hidup perkotaan (Müller, 2020)(Federal Commission for Nutrition, 2018). Menurut Indonesian Vegetarian Society jumlah vegetarian di Indonesia semakin semakin bertambah saat ini angkanya mencapai 60.000 orang. (Setiyani and Wirawanni, 2013). Sampai saat ini telah banyak tulisan mengenai diet vegan namun belum ada yang mengulas risiko diet vegan pada ibu hamil dan ibu menyusui terhadap kejadian penyakit rakitis nutrisi. Mengingat kesehatan tulang sangat penting bagi kesempurnaan kehidupan anak di masa selanjutnya maka penulis melakukan review literatur yang bertujuan untuk menyusun bukti ilmiah terjadinya penyakit rakitis nutrisi akibat diet vegan pada ibu hamil dan ibu menyusui.

Pola makan vegan berpotensi buruk terhadap kekuatan tulang. (Menzel et al., 2021). Iguacel et al., menegaskan bahwa diet vegetarian berisiko negatif terhadap kesehatan tulang anak. (Iguacel et al., 2019). Pola diet seperti itu miskin nutrisi penting seperti protein, kalsium, dan vitamin $D$ yang dapat menganggu metabolisme tulang. Pola makan vegan dapat menurunkan kadar vitamin $\mathrm{D}$ dan meningkatkan konsentrasi serum hormon paratoroid yang akan memicu peningkatan aktifitas perusakan tulang (Hansen et al., 2018). Ibu hamil yang berpola makan vegan berpotensi melahirkan bayi dengan KMK (Kecil Masa kehamilan) dan berat badan lahir rendah. Pola makan tersebut dapat menimbulkan gangguan kesehatan tulang anak walaupun bayi mendapat ASI ekslusif. Diet seperti ini dapat menimbulkan gangguan kesehatan tulang anak permanen (Avnon et al., 2020; Lemoine et al., 2020). Kondisi ini disebabkan karena kurangnya kadar vitamin $D$, dan kadar kalsium atau kombinasi keduanya (Munns et al., 2016). Pertumbuhan tulang membutuhkan mineral namun bila kebutuhan tersebut tidak terpenuhi maka dapat menimbulkan penyakit rakitis (Sahay and Sahay, 2012).

\section{METODE}

Review literatur ini dilakukan dengan menggunakan metode review naratif. Penulis melakukan penyusunan bukti empiris untuk menjawab tujuan penelitian. Penelusuran literatur dilakukan dengan menggunakan mesin pencarian google dan 
google schoolar. Kata kunci yang digunakan adalah vegan diet, rickets nutritional, management of rickets, vegan pregnancy, vegan breastfeeding. Kriteria inklusi yang digunakan adalah artikel di jurnal nasional dan internasional berupa hasil penelitian, review dan laporan kasus.

\section{PEMBAHASAN}

Sebagian besar literatur membahas manfaat dan risiko diet vegan dari perspektif ilmu dasar, klinis dan kesehatan masyarakat. Dari perpektif ilmu dasar dibahas faktor risiko dan mekanisme terjadi nya rakitis nutrisi. Secara klinis dibahas mengenai pengertian, penyebab, skrining, diagnosis, dan penatalaksanaan rakitis nutrisi. Strategi pencegahannya dibahas dari perspektif kesehatan masyarakat. Literatur tersebut memperlihatkan bukti ilmiah risiko terjadinya penyakit rakitis nutrisi akibat diet vegan pada ibu hamil dan menyusui. Pembahasan lebih rinci dapat dilihat di bawah ini.

\section{Rakitis Nutrisi}

Rakitis nutrisi adalah penyakit rakitis yang disebabkan oleh asupan nutrisi yang kurang. Kondisi ini menimbulkan gangguan proliferasi kondrosit dan defek mineralisasi oteoid dan mineralisasi lempeng pertumbuhan. Nutrisi yang kurang biasanya vitamin D dan kalsium (Munns et al., 2016). Anak dengan penyakit tersebut biasanya sering gelisah dan mudah tersinggung, terjadi juga keterlambatan perkembangan (delayed milestone) dan mengeluh nyeri tulang. Secara fisik terlihat adanya gangguan postur tubuh, gangguan struktur dan fungsi tulang. Pembengkakan sendi dan pembesaran tulang sendi pergelangan tangan dan sendi lutut, kelainan bentuk tulang kepala, bentuk tulang dada seperti tasbeh, kelainan bentuk sendi lutut yaitu genu valgum dan genu varum. Genu varum cenderung muncul pada bayi dengan Rakitis ketika mulai menahan beban atau berjalan. Deformitas Knock-knees (genu valgum) dan wind-swept (genu valgum kanan dan genu varum kiri) dapat terjadi dengan bertambahnya usia anak (Reginato and Coquia, 2003; Munns et al., 2016; Thandrayen and Pettifor, 2018). Tulisan ini menjelaskan konsep rakitis dari perspektif bidang muskuloskeletal dan pengertian ini telah menjadi konsensus dunia. Rakitis dapat disebabkan karena berbagai sebab seperti hipofosfatemia, hipokalsemia dan lainnya. Kondisi ini secara langsung menurunkan kadar vitamin $D$ dan menghambat mineralisasi protein matriks tulang (Fukumoto et al., 2015; Whyte and Thakker, 2009). Rakitis sering terjadi pada bayi, sampai rentang usia yang lebih tua antara 2 sampai dengan 15 tahun (Cesur et al., 2011). WHO menyebutkan bahwa prevalensi Rakitis gizi berkisar 2.7 per 1000 
Rakitis Nutrisi Akibat Diet Vegan pada Ibu Hamil dan Menyusui

Basuki Supartono, Ayola Dewi Utami, Prita Kusumaningsih

anak (WHO, 2019) bahkan di Eropa Rakitis masih umum terjadi pada pertengahan abad ke-20 (Uday and Högler, 2017). Pengertian rakitis nutrisi dari perspektif klinis, etiologi, dan epidemiologi ini sangat membantu dalam penatalaksanaan penyakit rakitis nutrisi.

\section{Metabolisme Vitamin D}

Defisiensi vitamin D masih menjadi masalah kesehatan dunia seperti disebutkan beberapa peneliti berikut ini. Insiden tahunan secara keseluruhan adalah 7,5 per 100.000, tetapi anak-anak dari etnis Asia Selatan memiliki insiden lima kali lipat lebih besar yaitu 38 per 100.000, dan mereka yang berasal dari etnis Afrika atau Afrika-Karibia berkulit hitam memiliki insiden 95 per 100.000 (Callaghan et al.,
2006). Penelitian di Indonesia pada tahun 2011 status vitamin D pada anak usia 2-4 tahun pada prevalensi defisiensi vitamin $\mathrm{D}$ $35 \%$ perkotaan $43 \%$ pedesaan dimana kadarnya $<50 \mathrm{nmol} / \mathrm{L}$ (Sandjaja et al., 2013). Salah satu sumber vitamin D adalah produk hasil aktivasi pro vitamin D kulit oleh radiasi ultraviolet sinar matahari (Gb.1). Aktivasi tersebut dipengaruhi pigmen kulit sehingga seseorang dengan kulit bewarna gelap lebih berisiko mengalami defisiensi vitamin D (Thacher, Pludowski, et al., 2016). Paparan sinar matahari yang kurang seperti terjadi pada populasi yang tinggal jauh dari garis khatulistiwa dapat juga menyebabkan defisiensi Vitamin D. (Jones et al., 2018). Vitamin $D$ ini sangat penting bagi pertumbuhan tulang anak. (Crowe et al., 2021).

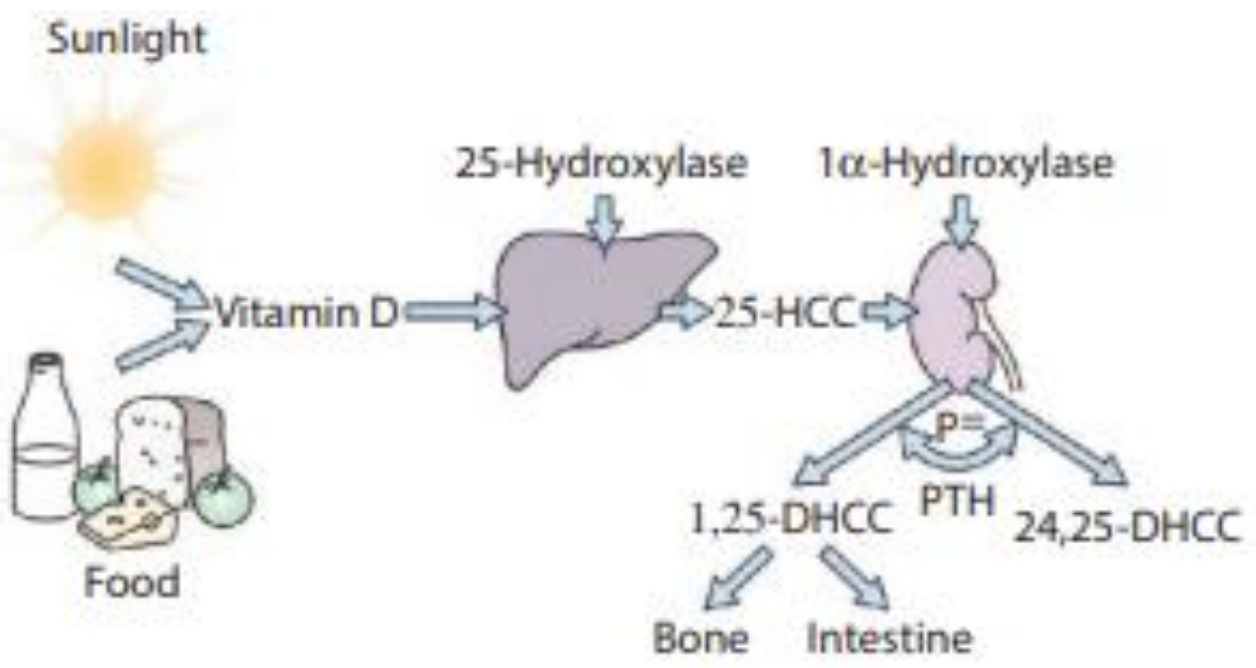

Gambar 1. Metabolisme Vitamin D (Blom, Warwick, and Whitehouse, 2017)

Vitamin D merupakan steroid yang larut dalam lemak, jenisnya adalah vitamin
D2 dan D3. Sinar ultraviolet yang dimaksud adalah ultraviolet B dengan radiasi (290- 
ISSN 1978-2071 (Print); ISSN 2580-5967 (Online) Jurnal IImiah Kedokteran Wijaya Kusuma 10(2) : 194-207, September 2021

315nm). Vitamin D merupakan bentuk inaktif. Konversi Vitamin D menjadi metabolit aktif terjadi di hati dengan bantuan enzim 25-Hydroksilase menjadi 25hidroksikalsiferol (25-OHD). Selanjutnya dilakukan dihidroksilasi di ginjal dengan bantuan enzim 1-alfa hidroksilase menjadi 1,25-dihydroxycholecalciferol $(1,25-(\mathrm{OH})$ 2D) atau kalsitriol. Selanjutnya 25-OHD diubah menjadi $24,25-(\mathrm{OH})_{2} \mathrm{D}$ yang tidak aktif. (Blom, Warwick and Whitehouse, 2017) Kalsitriol adalah hormon aktif, yang berfungsi meningkatkan kadar kalsium dalam darah bila terjadi defisiensi kalsium. Konversi terakhir vitamin D diaktifkan oleh hormon paratiroid $(P T H)$, dan hormon lain seperti estrogen dan prolaktin atau keadaan defisiensi fosfat. Dalam keadaan kadar hormon PTH turun dan kadar fosfat tinggi maka 25-OHD dirubah menjadi 24,25$(\mathrm{OH})_{2} \mathrm{D}$. Dalam kondisi keseimbangan kalsium negatif, maka terjadi pembentukan 1,25- $(\mathrm{OH})$ 2D. Hal ini juga merupakan respon terhadap pengeluaran hormon $P T H$. Meningkatnya kadar $1,25-(\mathrm{OH})_{2} \mathrm{D}$ akan membuat kadar kalsium menjadi normal. Senyawa $1,25-(\mathrm{OH})_{2} \mathrm{D}$ ini membantu peningkatan absorpsi kalsium di saluran cerna. (Blom, Warwick and Whitehouse, 2017). Orang dewasa dan lansia membutuhkan 400-800 IU (10-20 $\mu \mathrm{g})$ per hari (Blom, Warwick and Whitehouse, 2017; Bikle and Christakos, 2020). Review ini menjelaskan pentingnya peran vitamin $\mathrm{D}$ bagi kesehatan tulang dan dalam penatalaksaan penyakit rakitis.

Mengapa Diet Vegan Menyebabkan Rakitis?

Diet vegan pada ibu hamil dan menyusui dapat menyebabkan terjadinya kekurangan vitamin D (Lemale et al., 2019). Vitamin $\mathrm{D}$ berperan penting dalam regulasi proses mineralisasi tulang. Kondisi hipokalsemia atau hipofosfatemia, memicu vitamin D dalam aktifitas resorpsi tulang untuk menjaga kadar kalsium dan fosfor dalam darah. Kondisi defisiensi vitamin D akan menimbulkan gangguan mineralisasi tulang (Sahay and Sahay, 2012). Penurunan kadar vitamin $\mathrm{D}(1,25-\mathrm{OHD})$ dalam tubuh akan memicu terjadinya penyakit rakitis. Ibu hamil dan menyusui yang berdiet vegan membahayakan kesehatan tulang anaknya. (Blom, Warwick and Whitehouse, 2017). Hansen menggarisbawahi bahwa diet vegan berpotensi menurunkan kualitas tulang. (Hansen et al., 2018). Pelaku diet vegan tersebut umumnya menghindari semua produk hewani seperti daging, ikan, kerang, susu, telur, dan madu. Pola makan seperti ini dapat menyebabkan anak kekurangan nutrisi sehingga mengganggu proses tumbuh kembangnya (Ferrara et al., 2017). Uraian ini menekankan pentingnya para dokter memberikan edukasi kepada ibu hamil dan menyusui pelaku diet vegan akan 
Rakitis Nutrisi Akibat Diet Vegan pada Ibu Hamil dan Menyusui

Basuki Supartono, Ayola Dewi Utami, Prita Kusumaningsih

bahaya diet tersebut terhadap anaknya. Kondisi rendahnya vitamin $\mathrm{D}$, dan kalsium memicu PTH untuk meningkatkan absorbsi di tubulus ginjal dan meningkatkan aktivitas 1-alfa hidroksilase. Hal ini menyebabkan peningkatan 1,25-dihidroksi vitamin $\mathrm{D}$. Peningkatan kadar PTH tersebut membuat hilangnya fosfor dalam urin. Penurunan kadar fosfor dan kalsium berefek terjadinya gangguan mineralisasi tulang (Misra et al., 2008). Kondisi tersebut menyebabkan penurunan kapasitas kalsifikasi matriks antarsel sehingga terjadi penumpukan kondrosit yang tidak teratur di lempeng pertumbuhan. Terjadi pelebaran lempeng pertumbuhan, gangguan mineralisasi di zona kalsifikasi, dan penurunan pembentukan tulang di zona osifikasi. Jaringan trabekula tulang menipis dan rapuh. Selanjutnya bagian metafisis tulang menjadi lebar dan membuat tulang berbentuk seperti corong atau "cup" (Blom, Warwick and Whitehouse, 2017). Mekanisme lain adalah penurunan kadar fosfat yang mengakibatkan penurunan apoptosis kondrosit hipertrofik di lempeng pertumbuhan dan penurunan mineralisasi jaringan spongiosa primer di daerah metafisis. Hipofosfatemia dapat terjadi juga akibat hiperparatiroidisme sekunder (Uday and Högler, 2017).

Ibu menyusui yang berdiet vegan perlu memperhatikan kualitas ASI nya agar tidak berisiko terhadap bayinya. Pertumbuhan bayi di usia 6 bulan pertama mungkin masih normal namun dapat saja terjadi gangguan di umur selanjutnya. Peneliti lain menyebutkan bahwa walaupun ibu vegan memberikan ASI selama enam bulan pertama namun masih mungkin terjadi masalah kesehatan anak (Agnoli et al., 2017). Alternatifnya adalah menambahkan diet vegan dengan formula khusus yaitu nasi protein terhidrolis yaitu Hydrolyzed rice protein-based formulas. (Lemoine et al., 2020). Anak yang disusui ibu vegan sering mengalami kekurangan vitamin B12 sehingga terjadi anemia dan keterlambatan perkembangan syaraf. Ibu vegetarian yang tidak memberi ASI, biasanya menggantinya dengan susu formula bayi berbahan dasar beras atau kedelai yang diyakini mengandung vitamin B12. (Agnoli et al., 2017; Lemale et al., 2019). Ibu vegan biasanya tidak mengkomsumsi ikan atau maknan hasil laut laut padahal makanan tersebut merupakan sumber utama asam eicosapentaenoic (EPA) dan docosahexaenoic acid (DHA). Akibatnya ASI perempuan vegetarian mempunyai kandungan DHA yang rendah. Beberapa peneliti menganjurkan pemberian susu formula bayi yang diperkaya DHA, dengan kandungan minyak nabati kaya omega-3 (colza, kenari, kedelai) dan alga. (Agnoli et al., 2017; Sebastiani et 
ISSN 1978-2071 (Print); ISSN 2580-5967 (Online) Jurnal IImiah Kedokteran Wijaya Kusuma 10(2) : 194-207, September 2021

al., 2019). Anak yang lebih besar dianjurkan mengkonsumsi rutin setiap hari minimal tiga produk nabati kaya kalsium. Contohnya sayuran hijau, almond, wijen, kedelai, tahu, tempe. Bila memungkinkan para ibu dapat mengkonsumsi air minum kaya kalsium. Pada prinsipnya suplementasi kalsium merupakan suatu keniscayaan untuk mendapatkan tulang yang sehat (Agnoli et al., 2017). Pandangan peneliti tersebut di atas memberikan bukti ilmiah dari perspektif basic sciences mengenai risiko terjadinya penyakit rakitis nutrisi akibat diet vegan pada ibu hamil dan menyusui.

\section{Skrining Dan Diagnosis Rakitis}

Skrining dan diagnosis rakitis nutrisi dapat dilakukan dengan menggunakan beberapa parameter yaitu riwayat penyakit, klinis, laboratorium dan radiologi. Riwayat penyakit meliputi riwayat menyusui, asupan kalsium, dan vitamin D. Tanda klinis Rakitis diantaranya adalah pelunakan tulang tengkorak (craniotabes), dahi menonjol, keterlambatan penutupan fontanel, pembengkakan pergelangan tangan, lutut, dan kaki serta deformitas sendi lutut (genu varum atau genu valgum) dan gangguan berjalan. Tanda spesifik adalah bentuk kostokondral seperti tasbih. Tanda spesifik lain adalah gangguan pertumbuhan linier (pendek), hipotonia otot, gangguan pertumbuhan gigi, gangguan perkembangan motorik. Dapat terjadi kejang (WHO, 2019; Jones et al., 2018) (Gambar 2-3).

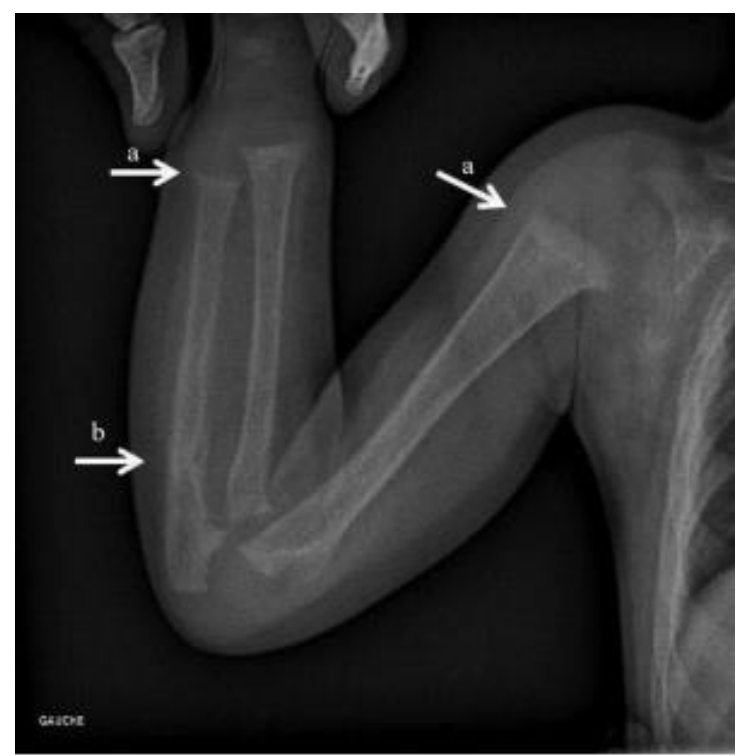

Gambar 2. (a) Pelebaran pergelangan tangan pada anak dengan Rakitis nutrisi (b) konsolidasi diafisis dengan fraktur ulna, dan osteopenia difus. (Lemoine et al., 2020) 


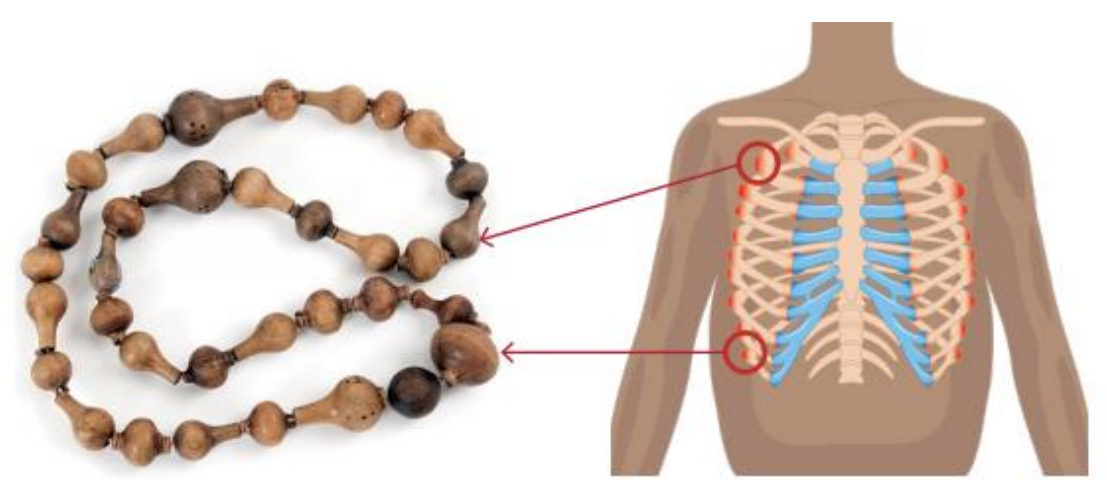

Gambar 3. Tulang dada bentuk tasbeh (WHO, 2019)

\section{Parameter Biokimia}

Parameter biokimia untuk skrining dan diagnostik Rakitis diantaranya adalah serum $25(\mathrm{OH}) \mathrm{D}$, serum kalsium, kalsium urin, serum fosfat, fosfat urin, serum PTH dan alkali fosfatase serum. Status Vitamin D diklasifikasikan berdasarkan tingkat serum 25-hidroksivitamin D 25(OH) D menjadi tiga kategori yaitu cukup (> $50 \mathrm{nmol}$ ) , insufisiensi (30-50 nmol) dan defisiensi : (<30 nmol) (Munns et al., 2016; WHO, 2019).

\section{Parameter Radiologis}

Pemeriksaan radiologis merupakan baku emas (gold standard) dalam diagnosa Rakitis. Tanda radiologis pasien Rakitis pada tahap awal penyakit dimulai dengan osteopenia dan penipisan tulang panjang kortikal, selanjutnya perubahan struktur lempeng metafisis (melebar, irregular, dan berjumbai) dan pembesaran sendi kostokondral anterior. Tanda lainnya adalah bowleg (mengarah ke genu varum atau genu valgum). Genu varum cenderung muncul pada bayi dengan Rakitis ketika mulai menahan beban atau berjalan. Tanda radiologis pada bayi dan anak lebih jelas pada pergelangan tangan, sedangkan pada anak yang lebih besar, lebih terlihat di area sendi lutut (Gambar 4) (Lemoine et al., 2020; Martel-Villagrán, Arias-Medina and García-Mardones, 2020; Thandrayen and Pettifor, 2018).

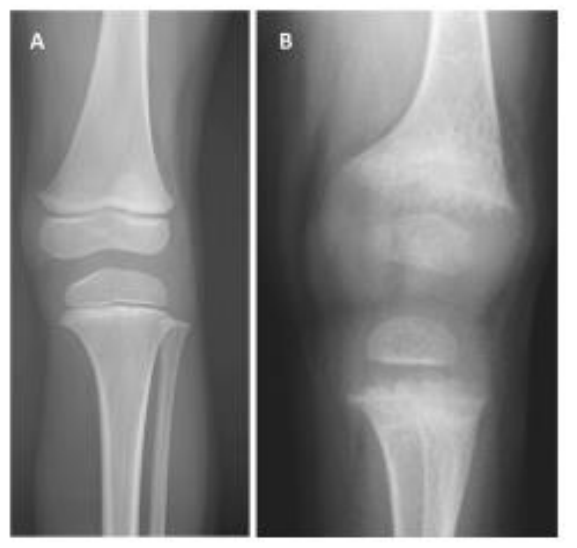

Gambar 4. (a) Gambaran lutut yang sehat, (b) Gambaran lutut pasien dengan Rakitis.(MartelVillagrán, Arias-Medina and García-Mardones, 2020)

Perkumpulan Penelitian Tulang dan Mineral Jepang dan Perkumpulan Endokrin Jepang menyebutkan kriteria diagnosis rakitis sebagai berikut: 
ISSN 1978-2071 (Print); ISSN 2580-5967 (Online) Jurnal IImiah Kedokteran Wijaya Kusuma 10(2) : 194-207, September 2021

a) Gambaran radiologis rakitis (metafisis cupping dan fraying, pelebaran lempeng epifisis)

b) Kenaikan kadar alkali posfatase

c) Penurunan kadar posfat (Hipoposfatemia) atau penurunan kadar kalium (hipokalemia)

d) Tanda klinis: kelainan bentuk (deformitas) tulang: pembengkakan sendi, genu varum / valgum, deformitas tulang belakang, deformitas tulang kepala: craniotabes, fontanel terbuka, tulang dada tasbih

Diagnosis rakitis pasti, bila pasien mempunyai seluruh gejala a,b,c,d. Diagnosis rakitis mungkin adalah bila pasien mempunyai tiga yaitu gejala a dan gejala $b$, dengan disertai salah satu dari gejala c atau gejala d (Fukumoto et al., 2015). Parameter klinis, laboratoris dan radiologis tersebut diatas menurut hemat penulis cukup praktis digunakan oleh para tenaga kesehatan di Indonesia dalam kegiatan skrining dan diagnosis rakitis nutrisi.

\section{Pencegahan Rakitis Nutrisi}

Pencegahan rakitis dapat dilakukan dengan suplementasi Vitamin D sebanyak $400 \mathrm{IU} /$ hari $(10 \mu \mathrm{g})$. Suplementasi ini dianjurkan untuk semua bayi sejak lahir sampai usia 12 bulan, terlepas dari cara pemberian makan mereka. Dosis Vitamin D dapat dinaikkan untuk beberapa populasi yaitu anak usia lebih dari usia 12 bulan, anak dan orang dewasa. Dosisnya adalah 600 IU/ hari (15 $\mu \mathrm{g}$ ) (Munns et al., 2016). FAO dan WHO merekomendasikan tambahan kalsium pada bayi yaitu $300-400 \mathrm{mg} /$ hari dan anak dengan dosis harian $500 \mathrm{mg}$ (1-3 tahun), $600 \mathrm{mg}$ (4-6 tahun), 700 (7-9 tahun) dan $1300 \mathrm{mg}$ ( 9-18 tahun) (WHO, 2019).

Pencegahan lain adalah anjuran kepada para ihu hamil agar mengkonsumsi Vitamin $D$ mulai bulan ketujuh kehamilannya (Uday et al., 2017). Dietary Guidelines for Americans (DGA) 2015-2020, menganjurkan agar ibu hamil menjaga kecukupan energi dan nutrisi. Kebutuhan energi ibu hamil setiap harinya adalah 340 kkal pada trimester kedua dan 452 kkal pada trimester ketiga atau berdasarkan European Food Safety Authority 260 kkal dan 500 kkal, masing-masing pada trimester ke 2 dan 3 (Sebastiani et al., 2019). Estimasi kebutuhan vitamin B12 untuk ibu hamil adalah 2,2 $\mu \mathrm{g} /$ hari dan ibu menyusui adalah $2,4 \mu \mathrm{g} /$ hari untuk menyusui. Selain vitamin B 12, pelaku diet vegan harus meningkatkan asupan folat yang tinggi agar dapat menutupi efek defiseinsi vitamin B12 (Sebastiani et al., 2019). Vegetarian dan vegan juga harus meningkatkan konsumsi kalsium yaitu 1.200 hingga 1.500 mg/ hari. Setara dengan delapan porsi makanan kaya kalsium. Ibu hamil harus menjaga kadar vitamin $25-\mathrm{OH}$ dalam darah berada di atas 
Rakitis Nutrisi Akibat Diet Vegan pada Ibu Hamil dan Menyusui

Basuki Supartono, Ayola Dewi Utami, Prita Kusumaningsih

$75 \mathrm{nmol} / \mathrm{L}$ (30 ng / mL). Ibu hamil sebaiknya mengosumsi dosis aman vitamin $D$ sebanyak 1.000 hingga 2.000 IU per hari, untuk mencegah bayi kekurangan vitamin $D$ (Sebastiani et al., 2019). Seperti anak non vegan maka anak-anak vegan harus mendapatkan suplementasi vitamin D sampai usia 18 bulan (Lemale et al., 2019). Literatur tersebut di atas menekankan pentingnya pencegahan penyakit rakitis nutrisi melalui suplementasi vitamin D namun konsensus ini belum seluruhnya menjadi kebijakan resmi di Indonesia.

\section{Tatalaksana Rakitis Nutrisi}

Konsensus global penatalaksanaan rakitis nutrisi menyarankan terapi melalui suplementasi vitamin $D$ dan kalsium yaitu sebagai berikut.

\section{Suplementasi vitamin D}

Suplementasi vitamin D sebaiknya dilakukan sejak bayi lahir sampai mencapai usia remaja. Dosis suplemetasi bervariasi sesuai umur dan indikasi. Bayi usia di bawah 3 bulan diberikan dosis $2.000 \mathrm{IU} /$ hari selama 12 pekan, setelah itu dilanjutkan dengan dosis pemeliharaan yaitu 400 IU. Bayi usia 3-12 bulan dapat diberikan 2.000 IU/ hari selama 12 pekan atau dapat juga diberikan dosis tunggal yaitu 50.000 IU, setelah itu diberikan dosis pemeliharaan 400 IU. Selanjutnya bagi usia 1-12 tahun diberikan vitamin D 3.000-6.000 IU/ hari selama 12 pekan atau dosis tunggal 150.000
IU. Bagi yang berusia lebih dari 12 tahun dapat diberikan 6000 IU/ hari selama 12 pekan atau dosis tunggal 300.000 IU, selanjutnya diberikan dengan dosis pemeliharaan 600 IU sampai kondisi teratasi (Munns et al., 2016). Konsumsi susu fortifikasi $200 \mathrm{~mL}$ dan Vitamin D 600 atau 1.000 IU setiap hari selama 12 pekan pada anak sekolah terbukti cukup mempertahankan kadar serum vitamin $D$ (25-hidroksivitamin D) $>50 \mathrm{nmol} / \mathrm{L}$ (Khadgawat et al., 2013).

\section{Suplementasi Kalsium}

Suplementasi kalsium diberikan sesuai indikasi dengan dosis tertentu. Penyembuhan rakitis membutuhkan dosis kalsium yang tinggi. Pemberian dosis tinggi (1000 mg / hari atau $2000 \mathrm{mg}$ / hari) setiap hari selama 24 pekan, terbukti memiliki efek penyembuhan radiologis lebih cepat dibanding dosis terendah (500 mg / hari). Pada kasus kejang tetani dapat diberikan kalsium intravena 10-20 mg / kg bb dalam waktu 5-10 menit, selanjutnya dievaluasi dan dapat diulang bila diperlukan. (Misra et al., 2008; Thacher, Smith, et al., 2016). Terapi vitamin D $(600.000$ IU dosis intramuskular tunggal), kalsium (75 mg / kg / hari kalsium secara oral) untuk jangka waktu 12 minggu atau kombinasi dari dua di atas, parameter laboratorium dan radiologis menjadi normal (Aggarwal et al., 2013). Rekomendasi terapi rakitis nutrisi 
tersebut merupakan hasil penelitian klinis para peneliti di atas dan telah diterapkan di Indonesia.

Diet vegan yang semakin populer dewasa ini terbukti memiliki risiko bagi kesehatan tulang. Para ibu hamil dan ibu menyusui yang melakukan diet vegan perlu memahami bahaya diet ini terhadap kesehatan tulang anaknya. Bila ibu hamil dan ibu menyusui tetap menghendaki melakukan diet vegan maka harus menyesuaikan dietnya agar memenuhi kecukupan nutrisi bagi kesehatan tulang. Demikian pula anak-anak yang lahir dari ibu vegan tersebut perlu mendapatkan nutrisi dan suplementasi yang cukup sesuai kebutuhan yang dianjurkan.

\section{KESIMPULAN}

Berdasarkan bukti ilmiah dari review literatur tersebut di atas dapat disimpulkan bahwa dapat terjadi rakitis nutrisi akibat diet vegan pada ibu hamil dan menyusui. Perlu dilakukan edukasi bagi ibu hamil dan menyusui agar tidak melakukan diet vegan selama masa kehamilan dan menuyusui. Keterbatasan literatur tersebut di atas adalah belum adanya bukti ilmiah mengenai efek waktu paparan diet vegan terhadap derajat penyakit rakitis nutrisi. Perlu penelitian lanjutan terkait masalah tersebut untuk menambah bukti ilmiah bahaya diet vegan pada ibu hamil dan menyusui bagi kesehatan tulang anak.

\section{DAFTAR PUSTAKA}

Aggarwal V, Seth A, Aneja S, Sharma B, Sonkar P, et al, 2013. Management of nutritional rickets in Indian children: A randomized controlled trial. Journal of Tropical Pediatrics. 59(2): 127-133.

Agnoli C, Baroni L, Bertini L, Ciappellano S, Fabbri A, et al, 2017. Position paper on vegetarian diets from the working group of the Italian Society of Human Nutrition', Nutrition, Metabolism and Cardiovascular Diseases. The societies SID, SISA and SINU and the Department of Clinical Medicine and Surgery at Federico II University in Italy, 27(12): 10371052.

Avnon T, Dubinsky EP, Lavie I, Bashi TB, Anbar R, Yogev $\mathrm{Y}$, et al, 2020. The impact of a vegan diet on pregnancy outcomes. Journal of Perinatology. Springer US.

Bikle D. and Christakos S, 2020. New aspects of vitamin $D$ metabolism and action - addressing the skin as source and target. Nature Reviews Endocrinology. Springer US, 16(4): 234-252. 
Blom A, Warwick D. and Whitehouse M, 2017. Apley and Solomon's System Of Orthopaedics and Trauma. 10th edn. Taylor \& Francis Group.

Callaghan AL, Moy RJD, Booth IW, Debelle G and Shaw NJ, 2006. Incidence of symptomatic vitamin $D$ deficiency. Archives of Disease in Childhood, 91(7): 606-607.

Cesur Y, Dogan M, Ariyuca S, Basaranoglu $\mathrm{M}$, et al, 2011. Evaluation of children with nutritional rickets', Journal of Pediatric Endocrinology and Metabolism, 24(1-2): 35-43.

Crowe FL, Mughal MZ, Maroof Z, Berry J, Kaleem M, et al, 2021. Vitamin D for growth and rickets in stunted children: A randomized trial. Pediatrics, 147(1).

Federal Commission for Nutrition, 2018. Vegan diets: review of nutritional benefits and risks. Expert report of the FCN'. Available at: https://www.eek.admin.ch/eek/e n/home/pub/vor-und-nachteilevegane-ernaehrung.html.

Ferrara P, Corsello G, Quattrocchi E, Aquila LD, Ehrich J, et al, 2017. Caring for Infants and Children Following Alternative Dietary Patterns. Journal of Pediatrics. Elsevier Inc., 187(1-2): 339-340.e1.

Fukumoto S, Ozono K, Michigami T,
Minagawa $\mathrm{M}$, Okazaki $\mathrm{R}$, et al, 2015. Pathogenesis and diagnostic criteria for rickets and osteomalacia -proposal by an expert panel supported by ministry of health, Labour and Welfare, Japan, the Japanese society for bone and mineral research and the Japan endocrine society. Endocrine Journal, 62(8): 665-671.

Hansen TH, Madsen MTB, Jørgensen NR, Cohen AS, Hansen T, et al, 2018. Bone turnover, calcium homeostasis, and Vitamin D status in Danish vegans. European Journal of Clinical Nutrition. Springer US, 72(7): 1046-1054.

Iguacel I, Miguel-Berges ML, Gomez-Bruton A, Moreno AL, Julian C, et al, 2019. Veganism, vegetarianism, bone mineral density, and fracture risk: A systematic review and metaanalysis. Nutrition Reviews, 77(1): 1-18.

Jones KDJ, Hachmeister CU, Khasira M, Cox L, Schoenmakers I, et al, 2018. Vitamin $D$ deficiency causes rickets in an urban informal settlement in Kenya and is associated with malnutrition. Maternal and Child Nutrition, 14(1): 1-8.

Khadgawat R, Marwaha RK, Garg MK, 
Ramot R, Oberoi AK, et al, 2013. Impact of vitamin D fortified milk supplementation on vitamin D status of healthy school children aged 10-14 years. Osteoporosis International, 24(8): 2335-2343.

Lemale J, Mas E, Jung C, Bellaiche $M$, Tounian P, et al, 2019. Vegan diet in children and adolescents. Recommendations from the French-speaking Pediatric Hepatology, Gastroenterology and Nutrition Group (GFHGNP). Archives de Pediatrie. Elsevier Masson SAS, 26(7): 442-450.

Lemoine A, Giabicani E, Lockhart V, Grimprel E and Tounian P, 2020. Case report of nutritional rickets in an infant following a vegan diet. Archives de Pediatrie. French Society of Pediatrics, 27(4): 219222.

Martel-Villagrán J, Arias-Medina A, and García-Mardones G, 2020. Usefulness of X-rays in the Differential Diagnosis of Hypophosphataemic Rickets. Advances in Therapy, 37: 89-94.

Menzel J, Abraham K, Stangl GI, Ueland PM, Obeid R, et al, 2021. Vegan Diet and Bone Health-Results from the Cross-Sectional RBVD Study. 1-16
Misra M, Pacaud D, Petryk A, Collett-Solberg PF and Kappy M, 2008. Vitamin D deficiency in children and its management: Review of current knowledge and recommendations. Pediatrics, 122(2): 398-417.

Müller P, 2020. Vegan Diet in Young Children. Nestle Nutrition Institute Workshop Series, 93: 103-110.

Munns CF, Shaw N, Kiely M, Specker BL, Thacher TD, et al, 2016. Global consensus recommendations on prevention and management of nutritional rickets. Hormone Research in Paediatrics, 85(2): 83106.

Reginato AJ and Coquia JA, 2003. Musculoskeletal manifestations of osteomalacia and rickets. Best Practice and Research: Clinical Rheumatology, 17(6): 1063-1080. Sahay M and Sahay R, 2012. Rickets-vitamin D deficiency and dependency. Indian Journal of Endocrinology and Metabolism, 16(2): 164.

Sandjaja S, Budiman B, Harahap H, Ernawati F, Soekatri M, et al, 2013. Food consumption and nutritional and biochemical status of 0.5-12-yearold Indonesian children: The SEANUTS study. British Journal of Nutrition, 110(SUPPL.3).

Sebastiani G, Barbero AH, Borrás-Novell C, 
Casanova MA, Aldecoa-Bilbao V, et $a l, 2019$. The effects of vegetarian and vegan diet during pregnancy on the health of mothers and offspring. Nutrients, 11(3): 1-29.

Setiyani DA and Wirawanni Y, 2013. Perbedaan Sindrom Metabolik Pada Wanita Vegetarian Tipe Vegan Dan Non Vegan. Journal of Nutrition College, 2(1): 111-117.

Thacher TD, Pludowski P, Shaw NJ, Mugha MZ, Munns CF, et al, 2016). Nutritional rickets in immigrant and refugee children. Public Health Reviews. Public Health Reviews, 37(1): 1-10. doi: 10.1186/s40985016-0018-3.

Thacher TD, Smith L, Fischer PR, Isichei CO, Cha SS, et al, 2016. Optimal Dose of Calcium for Treatment of Nutritional Rickets: A Randomized Controlled Trial. Journal of Bone and Mineral Research, 31(11): 2024-2031.

Thandrayen $\mathrm{K}$ and Pettifor JM, 2018. The roles of vitamin $D$ and dietary calcium in nutritional rickets. Bone Reports. Elsevier, 8(October 2017), 81-89.

Uday S, Kongjonaj A, Aguiar M, Tulchinsky T and Högler W, 2017. Variations in infant and childhood vitamin D supplementation programmes across Europe and factors influencing adherence. Endocrine Connections, 6(8): 667-675.

Uday S and Högler W, 2017. Nutritional Rickets and Osteomalacia in the Twenty-first Century: Revised Concepts, Public Health, and Prevention Strategies. Current Osteoporosis Reports. Current Osteoporosis Reports, 15(4): 293302.

WHO, 2019. Nutritional rickets: a review of disease burden, causes, diagnosis, prevention and treatment'. World Health Organisation.

Whyte MP and Thakker RV, 2009. Rickets and osteomalacia. Medicine. Elsevier Ltd, 37(9): 483-488. 